\title{
Komunizm kosmiczny
}

Fredric Jameson zauważył, że myślenie utopijne, które jako jedyne może wytwarzać wizje alternatywy dla globalnego status quo, powinno w naszych czasach rozpocząć się od gruntownej terapii dystopii (Jameson 2016, 54): innymi słowy, od wyleczenia nas z antyutopijnych lęków, które zakorzeniła w nas cyniczna ideologia neoliberalizmu. Niezbędnym elementem tej pracy terapeutycznej jest otwarte skonfrontowanie się z najbardziej traumatycznymi obrazami utopijnymi minionego stulecia, których wizja doskonałego społeczeństwa i nowego człowieka automatycznie budzi skojarzenia z najgorszymi totalitarnymi ekscesami. Jednak być może właśnie tam, w tych skompromitowanych i „nieludzkich” wręcz ze współczesnej perspektywy projektach (nieludzkich zarówno w sensie etycznym, jak i ekologicznym), tkwią utopijne ślady warte ocalenia, potencje zdolne do uruchomienia naszej spetryfikowanej wyobraźni tak, by mogła na nowo wymyślać inne, lepsze światy. Ten problem wydaje się szczególnie aktualny w dobie katastrofy klimatycznej i zmierzchu demokracji liberalnej: „Stare umiera, a nowe nie potrafi się narodzić" (Gramsci 1991, 427).

Najbardziej odważna i radykalna komunistyczna utopistyka - enfant terrible europejskiego modernizmu - projektowała nie tylko wzorcowe modele społeczeństwa i jego politycznej organizacji, lecz sięgała znaczenie dalej, w kierunku przemiany relacji pomiędzy człowiekiem a jego środowiskiem naturalnym. Ludzkość miała całkowicie podporząakować 
Ludzkość miała całkowicie podporządkować sobie przyrodniczą

konieczność - nie tylko tu, na ziemi, lecz

także w przestrzeni kosmicznej! sobie przyrodniczą konieczność - nie tylko tu, na ziemi, lecz także w przestrzeni kosmicznej! Już Marks w swoich Rękopisach filozoficzno-ekonomicznych postulował "humanizację przyrody” (Marks [1844] 1960, 579). Do realizacji tego zadania z pełnym rozmachem przystąpiła władza radziecka - i to zanim jeszcze ktokolwiek usłyszał o Stalinie, z jego zawracaniem nurtów rzek, wznoszeniem zapory na Dnieprze czy budowaniem Kanału Białomorskiego. Już we wczesnych latach dwudziestych Lenin przedstawił swój flagowy projekt utopijno-modernizacyjny GOELRO - Narodowy Plan Elektryfikacji Rosji - którego celem było postawienie technicznych fundamentów pod wielką budowlę socjalizmu: „Komunizm - to Władza Radziecka plus elektryfikacja całego kraju” (Lenin 1955, 527). Dzięki niej zacofane peryferia Rosji miały zostać oświecone - dosłownie i metaforycznie - a w konsekwencji wsie połączyłyby się z miastami, a chłop przeobraziłby się w proletariusza. Cały proces industrializacji, przekształcenia ogromnych rolniczych prowincji w dymiące fabryki splecione torami kolejowymi i okalane regulowanymi kanałami rzecznymi, stanowił dla bolszewików - od prawa do lewa konieczną materialną bazę dla socjalistycznego społeczeństwa. Najwyższą stawką tego przedsięwzięcia był podbój przyrody, tego, co chaotyczne i nieokiełznane, przez potęgę ludzkiej racjonalności. Trafnie wyraził to Trocki pod koniec Literatury i rewolucji, gdy następująco szkicował kontury komunistycznej przyszłości: „Człowiek sam zajmie się wyznaczaniem nowych pasm górskich i koryt rzek, nieustannie udoskonalając przyrodę. $\mathrm{Na}$ koniec wreszcie sam przebuduje ziemię, jeśli nie wedle własnego obrazu, to przynajmniej zgodnie z własnym smakiem” (Trotsky [1924] 2007). A zatem: „Stworzyć nową, "ulepszoną odmianę« człowieka - oto przyszłe zadanie komunizmu" (cyt. za: Figes 2011, 442). Wizja Trockiego nie była wcale odosobniona, wyrażała bowiem idee masowego ruchu - konstruktywistów, futurystów, suprematystów i innych rewolucyjnych awangardystów - aktywnego w sztuce, architekturze, psychologii, pedagogice i naukach technicznych; ruchu, który w latach dwudziestych gromadził tysiące ludzi w Rosji Radzieckiej. Można go śmiało uznać za prekursora dzisiejszego posthumanizmu (Wark 2015). Wierzono, że nauka i technologia służyć będą nie tylko komunistycznej transformacji społeczno-ekonomicznej, lecz także bardziej fundamentalnemu przeobrażeniu przyrody i samej istoty ludzkiej. Dlatego tak istotną rolę w owym ruchu odgrywała fascynacja maszyną, elektryfikująca futurologiczną wyobraźnię bolszewików. Najistotniejszym wyznawcą jej kultu był radziecki inżynier i poeta Aleksiej Gastiew, który, zainspirowany organizacyjnymi ideami Fredericka Taylora, projektował futurystyczne społeczeństwo, w którym człowiek i maszyna ustanowić miały nierozdzielną 
jednię - mechanizacji miał ulec nie tylko proces pracy, lecz cała sfera reprodukcji społecznej, jednostkę zastąpiłby zaś „kolektywny ludzki robot”, a wówczas: „Wszelkie emocje staną się zbędne, a dusza ludzka nie będzie już mierzona »krzykiem ani uśmiechem, lecz zaworem ciśnieniowym lub prędkościomierzem «" (Figes 2011, 459). Gastiew stworzył również termin „biomechanika”, a swoje eksperymentalne pomysły wcielał w życie kierując założonym w 1920 roku Centralnym Instytutem Pracy.

Tragiczny okres wojny domowej w Rosji i następująca po nim NEP-owska stabilizacja doprowadziły do prawdziwej eksplozji utopijnych obrazów i milenarystycznych pragnień, w ramach których kluczowym problemem świata porewolucyjnego przestawały być stosunki międzyludzkie, a stawała się nim relacja człowieka do przyrody (na temat historii tych być może najbardziej brawurowych i szalonych w epoce nowoczesnej rewolucyjnych wizji polityczno-estetycznych zob. Stites 1989). Szczególne miejsce zajmowały tu dwa zagadnienia: cielesnej nieśmiertelności oraz podróży kosmicznych. Oba miały genezę w powstałym u schyłku dziewiętnastego wieku rosyjskim kosmizmie. Jego naczelnym teoretykiem był Nikołaj Fiodorow, łączący w swojej myśli prawosławną ortodoksję i carską ideologię z nieograniczoną wiarą w możliwości kosmicznych technologii. Opracował on bardzo osobliwą naukowo-mistyczną utopię, której celem był tak zwany „wspólny czyn” ludzkości, czyli zwycięstwo nad śmiercią, wskrzeszenie umarłych i kolonizacja całego wszechświata (Fiodorow 2012). Fiodorow zainspirował popularny w latach dwudziestych ruch bolszewickich biokosmistów (Pomorski 1996), których hasło brzmiało „nieśmiertelność i międzyplanetarność” - tradycyjne cele religii miały zostać urzeczywistnione w życiu ziemskim przez rozwój nauki i techniki (należeli do niego m.in. inżynier rakietowy i „ojciec radzieckiej kosmonautyki” Konstantin Ciołkowski oraz twórca mauzoleum Lenina Leonid Krasin). Biokosmiści zapoczątkowali radzieckie sny o podboju i kolonizacji kosmosu, zmaterializowane już trzy dekady później, gdy Sputnik 1 dotarł na orbitę okołoziemską.

Innym źródłem kosmicznej futurologii była głośna utopia ekscentrycznego bolszewika Aleksandra Bogdanowa Czerwona Gwiazda z 1908 roku, opisująca modelowe techno-komunistyczne, cybernetyczne społeczeństwo Marsjan, wolne od wyzysku i pełne cywilizacyjnego dostatku (Bogdanov 1984). Sam Bogdanow stał się zresztą już w czasach radzieckich głównym teoretykiem Proletkultu, najważniejszego laboratorium rewolucyjno-utopijnej wyobraźni rosyjskiej awangardy (ponadto był związany z gnostycko-marksistowskim nurtem „bogotwórstwa”, wraz z Maksymem Gorkim i Anatolijem Łunaczarskim, a także prowadził

Tragiczny okres wojny domowej w Rosji

i następująca po nim NEP-owska stabilizacja doprowadziły do prawdziwej eksplozji utopijnych obrazów i milenarystycznych pragnień, w ramach których kluczowym problemem świata porewolucyjnego przestawały być stosunki międzyludzkie, a stawała się nim relacja człowieka do przyrody. 
badania nad transfuzją krwi i technologiami odmłodzenia ciała, w wyniku których śmiertelnie zachorował). Do kosmicznej wizji komunizmu w swoich utopiach (i anty-utopiach) nawiązywali także Andriej Płatonow (Dót, Czewengur) czy Aleksiej Tołstoj (Aelita i Eksperyment inżyniera Garina). Płatonow, w młodości biokosmista, wyobrażał sobie, że w komunistycznej przyszłości ludzkość zostanie ostatecznie wyzwolona od biologicznego cyklu reprodukcji: wraz ze zniknięciem podziału na klasy, zniknąć miał też podział na płcie. Nowy bezpłciowy człowiek uwolni się wreszcie od toski - ubogiego życia - czyli od wszelkich trosk materialnych i społecznych, wiódł będzie zatem prawdziwie wolną egzystencję w świecie, w którym krzywda przyrody także została odkupiona (Chehonadskih 2017). Futurystyczna narracja stanowiła, jak widzimy, pole rozważań zagadnień filozoficznych i moralnych dotyczących tak nauki i sumienia, jak proletariatu i rewolucji - a wizja całkowitego opanowania przyrody przez człowieka ścierała się z projektem totalnego wyzwolenia wszystkich form życia, tych ludzkich i tych zwierzęcych... (Žižek 2021, 77). Z tego intelektualnego fermentu powstały nie tylko ekstrawaganckie spekulacje radykalnych inteligentów oraz powieści science-fiction (w samym roku 1927 opublikowano ich zgoła pięćdziesiąt!), ale także radziecka kosmonautyka i projekt programu kosmicznego, czego najlepszym dowodem jest nowatorska rozprawa Jurijego Kondratiuka z 1925 roku Podbój przestrzeni międzyplanetarnej.

Filozoficznej ramy dla tych wizji polityczno-kosmicznych dostarcza Ernst Bloch, który w Das Prinzip Hoffnung (Zasadzie nadziei; Bloch 1985) wyciąga ostateczne pojęciowe konsekwencje z Marksowskiego postulatu „humanizacji natury”. Dla Blocha radykalna utopia - której ślady tropi na przestrzeni dziejów - obejmuje nie tylko stosunki społeczne, lecz cały wszechświat. Podobnie jak dla radzieckich kosmistów, idzie tutaj o totalną reorganizację świata, o zmianę samej natury. Bloch nie podziela jednak ich oświeceniowej fantazji o racjonalnym podmiocie całkowicie panującym nad wszelkim zewnętrzem, o demiurgicznej technologii odwracającej naturalny bieg rzeczy. Konstruuje więc zorientowaną na przyszłość kosmologię, w której bezklasowe społeczeństwo i harmonijna koegzystencja człowieka i przyrody stanowią niejako cel samej natury - są jej wewnętrzną teleologią. To natura - za pośrednictwem ludzkości - zmierza do komunizmu. Zamiast humanistycznego prometeizmu bolszewików „utopia konkretna” Blocha kieruje nas w stronę idei przednowoczesnego kosmosu, w którym jedność człowieka i przyrody nie została jeszcze rozbita. Projekt ten można zatem określić mianem postępowej kosmologii, której telos stanowi odzyskanie utraconej pleromy - pierwotnej ontologicznej pełni. 
$\mathrm{Na}$ antypodach Blocha sytuuje się kosmologia Ewalda Iljenkowa, czyli najważniejszego powojennego filozofa w Związku Radzieckim (Žižek 2018). Przekładem Kosmologii ducha, autorstwa Iljenkowa, otwieramy niniejszy numer Praktyki Teoretycznej. Ten niezwykły spekulatywny tekst autor napisał w latach pięćdziesiątych i nie opublikował go za swojego życia. Opierając się na Spinozie, Heglu i Dialektyce przyrody Engelsa, stawia w nim śmiałą hipotezę wydedukowaną z zasad materializmu dialektycznego: skoro myśląca materia stanowi najdoskonalszą formę organizacji bytu, to stoi przed nią kosmologiczny obowiązek wobec przyrody - ma powstrzymać „śmierć cieplną” kosmicznej materii, a może tego dokonać, „świadomie wytwarzając kosmiczną katastrofę - początkującą proces odwrotny do »termicznego umierania " kosmicznej materii, tj. powodując proces prowadzący do odrodzenia umierających światów” (Iljenkow 2021, 42). Myślący duch, w pewnym momencie rozwoju gatunku ludzkiego, poświęci samego siebie w imię rekreacji wielkiego wybuchu, inicjującego nowe uniwersum, w którym za jakiś milion lat ponownie zrodzi się myśląca materia. Tylko wtedy nieubłagany fakt ludzkiej śmierci może właściwie zyskać materialistyczne usprawiedliwienie. W przeciwieństwie do Blocha i jego postępowej teleologii prowadzącej do absolutnego pojednania myśli i przyrody, Iljenkow opracowuje cykliczną kosmologię, której momentem koniecznym jest „światowy pożar” i zagłada ludzkości, spłacającej swój dług wobec „Matki Natury”. Pozytywnemu finałowi ontologii Blocha radziecki filozof przeciwstawia nieredukowalną negatywność samego bytu, dla której „wszystko, co powstaje, warte tylko tego, by istnieć przestało" (Goethe 2019, 36). Politycznym warunkiem tego radykalnego samopoświęcenia człowieka jest oczywiście w pełni rozwinięte społeczeństwo komunistyczne: „Miną miliony lat, narodzą się i zejdą do grobu tysiące pokoleń, na Ziemi powstanie prawdziwie ludzki system warunków działania - rozkwitnie społeczeństwo bezklasowe, kultura duchowa i materialna, dzięki którym dopiero ludzkość będzie w stanie wypełnić swój wielki ofiarny obowiązek wobec przyrody" (Iljenkow 2021, 46). Kosmologię ducha w szerokim kontekście filozoficzno-politycznym osadza Alexei Penzin w artykule „Przygodność i konieczność w Kosmologii ducha Ewalda Iljenkowa”, którego przekład zamieszczamy w numerze. Rosyjski badacz nie tylko rekonstruuje genealogię rozprawy i proponuje jej filozoficzną interpretację, ale także zestawia ją ze współczesnymi nurtami myśli spekulatywnej (głównie Alaina Badiou i Quentina Meillassoux). Na tym tle hipoteza Iljenkowa zyskuje niespodziewaną aktualność i istotne implikacje dla polityki komunistycznej.

Pozytywnemu finałowi ontologii Blocha radziecki filozof przeciwstawia nieredukowalną negatywność samego bytu, dla której „wszystko, co powstaje, warte tylko tego, by istnieć przestało". 
Za kontrapunkt dla kosmologii pozytywnej Blocha i negatywnej Iljenkowa można uznać projekt „astrologii politycznej” Katarzyny Czeczot. W numerze prezentujemy jej esej „O wpływach ciał niebieskich. Wstęp do astrologii politycznej”. Autorka, zamiast poszukiwać w przyszłości ostatecznego celu, do którego dąży natura, przygląda się związkom człowieka i przyrody w przednowożynym uniwersum, badając pojęcie wpływu. O ile marksistowskich kosmologów interesował wpływ człowieka na świat pozaludzki, o tyle dla astrologii - wypartej przez oświeceniową naukę - istotny jest wpływ ciał niebieskich na człowieka. Postulowane przez Czeczot odzyskanie ukrytych w tradycji astrologicznej więzi łączących ludzi z ich środowiskiem naturalnym zyskuje wymiar polityczny w dobie kryzysu klimatycznego.

Do kosmicznych spekulacji nawiązuje również Agnieszka Urbańczyk, w swoim tekście „Terra Ignota. Marksizm kosmiczny jako marksizm apofatyczny”. Interpretuje w nim utopię Ady Palmer Terra Ignota, ukazującą przyszłościowe społeczeństwo Utopian na Marsie, w którym podobnie jak w radzieckich wizjach z lat dwudziestych - zanikowi uległy podziały płciowe i nierówności społeczne. Postawa polityczna Utopian zinterpretowana zostaje jako przykład marksizmu apofatycznego China Miéville'a. Choć nie dostarcza on gotowych projektów, to wciąż może być narzędziem krytyki współczesności i bodźcem pobudzającym do działania.

Kolejny artykuł, który obraca się wokół orbity komunizmu kosmicznego, poświęcony jest jednemu z jego czołowych reprezentantów - Aleksandrowi Bogdanowowi. Poznajemy go jednak nie od strony utopii literackich, filozoficzno-politycznych dyskusji z Leninem czy działalności w awangardowym Proletkulcie, tylko z perspektywy mniej znanej dyscypliny naukowej, którą sam stworzył - tektologii (uniwersalnej nauki o organizacji). Jej podstawy i filozoficzne inspiracje przedstawia Marta Hofman w tekście „Tektolologia Aleksandra Bogdanowa - nauka przyszłości”. Rekonstruując koncepcje metodologiczną Bogdanowa, autorka dostrzega w niej antycypacje ogólnej teorii sprawnego działania Tadeusza Kotarbińskiego.

Drugi cykl tekstów w numerze poświęcony jest Benjaminowi Brattonowi - współczesnemu kalifornijskiemu teoretykowi dizajnu i socjologowi. Bratton pracuje jako dyrektor programu badawczego The Terraforming w ramach Moskiewskiego Strelka Institute (Rosja, jak widzimy, powraca jako kraina futurologicznych wizji), który ma na celu projektowanie rozwiązań kluczowych planetarnych problemów, w szczególności tych powiązanych z katastrofą klimatyczną. Wprowadzenie do myśli Brattona przygotował Michał Owczarek w artykule „Planować w skali 
planetarnej”. Autor koncentruje się przede wszystkim na dwóch aspektach tej teorii: roli aparatów obliczeniowych w kryzysie klimatycznym oraz koncepcji Stosu - modelu opisującego współczesny globalny układ odniesień. Pod wpływem Brattona Owczarek zastanawia się także nad koniecznymi warunkami racjonalnej polityki przyszłości.

W numerze publikujemy pierwszy przekład Brattona na język polski - tekst „O antropolizie”. Teoretyk zastanawia w nim się nad relacją atropogenezy i antropocenu, zestrojeniem człowieka i planety oraz jego polityczno-społecznymi konsekwencjami. Zamieszczamy również komentarz do przekładu autorstwa tłumacza - Jakuba Wolaka - „Uziemienie. Filozoficzne marginalia do The Stack i $O$ antropolizie Benjamina Brattona”. Krytycznie omawiając koncepcję Stosu Wolak sytuuje Brattona w ramach najnowszej historii intelektualnej, ukazując jego inspiracje i założenia teoretyczne. Natomiast odnosząc się do tekstu „O antropolizie”, próbuje on rozwiązać niektóre z wcześniej zdiagnozowanych problemów Stosu.

Na koniec powracamy do radzieckiego kosmosu, a raczej do nostalgii za nim, którą zajmuje się Roman Privalov w swoim artykule „Is the Future Soviet? USSR-2061 and the Reality of Utopia”. Badając rosyjski futurystyczny projekt online USSR-2061 (prezentujący nowy utopijny ZSRR, sto lat po locie Gagarina w kosmos) autor zastanawia się nad relacją utopizmu i realizmu - nad tym, jak można wykorzystać utopię do rzeczywistej zmiany świata. Analizując zagrożenia, które nieustannie czyhają na utopijne wizje i narracje, Privalov z USSR-2061 próbuje z pomocą Bruno Latoura - wydobyć alternatywną koncepcję przestrzeni, umożliwiającą budowanie lepszej przyszłości.

Prezentowane w numerze teksty zachęcają czytelniczki do wspólnego namysłu nad relacjami futurologii i nauki: czy bez szalonych, utopijnych wizji rekreacji wszechświata wystrzelono by w kosmos rakietę Wostok? A także, co chyba istotniejsze z dzisiejszej perspektywy: czy w dobie kryzysu antropocenu koncepcje człowieka swobodnie modelującego przyrodę mogą służyć za coś więcej niż przestrogę? Czy to właśnie niezachwiana wiara bolszewików w postęp techniczny i sen o modernizacji nie przyczyniły się najbardziej do ostatecznej porażki radzieckiego projektu? W związku z tym, jakie lekcje z teorii i praktyki eksploracji kosmosu można wyciągnąć dla współczesnej walki z katastrofą ekologiczną? Może nadszedł czas, aby pomysły kolonizacji Marsa odebrać 
Elonowi Muskowi i nie zostawiać przyszłości naszego układu słonecznego w rękach kapitału? Kosmos stanowił punkt kulminacyjny nowoczesnych marzeń o radykalnym przeobrażeniu rzeczywistości, pora więc odzyskać go dla myślenia lewicowego, które, pogrążone w pełnym rezygnacji marazmie, cierpi na deficyt energii twórczej. Dlatego bardziej niż kiedykolwiek potrzebuje ono utopijnego paliwa rakietowego.

\section{Wykaz literatury}

Bloch, Ernst. 1985. Das Prinzip Hoffnung - 3 Bände. Frankfurt am Main: Suhrkamp.

Bogdanov, Alexander. 1984. Red Star: The First Bolshevik Utopia, red. Loren R. Graham i Richard Stites. Tłum. Charles Rouge. Bloomington-Indianopolis: Indiana University Press.

Chehonadskih, Maria. 2017. Soviet Epistemologies and the Materialist Ontology of Poor Life: Andrei Platonov, Alexander Bogdanov and Lev Vygotsky. (PhD thesis). Kingston: London. https://eprints.kingston. ac.uk/id/eprint/38850/.

Figes, Orlando. 2011. Taniec Nataszy. Z dziejów kultury rosyjskiej. Tłum. Władysław Jeżewski. Warszawa: Wydawnictwo Magnum.

Fiodorow, Nikołaj. 2012. Filozofia wspólnego czynu. Tłum. Cezary Wodziński i Michał Milczarek, wstęp Michał Milczarek. Kęty: Wydawnictwo Marek Derewiecki.

Goethe, Johann Wolfgang. 2019. Faust. Tragedii czesść pierwsza i druga. Tłum. i posłowie Andrzej Lam. Warszawa: Oficyna Wydawnicza ASPRA-JR.

Gramsci, Antonio. 1991. Zeszyty filozoficzne, red. i wstęp Sław Krzemień-Ojak. Tłum. Barbara Sieroszewska i Joanna Szymanowska. Warszawa: Wydawnictwo Naukowe PWN.

Iljenkow, Ewald. 2021. „Kosmologia ducha. Próba stworzenia ogólnego zarysu obiektywnej roli myślącej materii w systemie światowych interakcji (filozoficzno-poetycka fantasmagoria, wsparta na zasadach materializmu dialektycznego).” Tłum. Krystian Szadkowski. Praktyka Teoretyczna 41(3): 19-48. https://doi.org/110.14746/prt.2021.3.2. Jameson, Fredric. 2016. "An American Utopia." W An American Utopia Dual Power and the Universal Army, red. Slavoj Žižek, 1-96. London - New York: Verso.

Lenin, Włodzimierz. 1955. „VIII Ogólnorosyjski Zjazd Rad.” W Dzieła, T. 31. Warszawa: Książka i Wiedza. 
Marks, Karol. (1844) 1960. „Rękopisy ekonomiczno-filozoficzne z 1844 r.” Tłum. Konstanty Jażdżewski i Tadeusz Zabłudowski. W Marks, Karol, i Fryderyk Engels. Dzieła, T.1. Warszawa: Książka i Wiedza.

Pomorski, Adam. 1996. Duchowy proletariusz. Przyczynek do dziejów lamarkizmu społecznego i rosyjskiego kosmizmu XIX-XX wieku (na marginesie antyutopii Andrieja Płatonowa). Warszawa: Wydawnictwo "Open”.

Sites, Richard. 1989. Revolutionary Dreams: Utopian Vision and Experimental Life in the Russian Revolution. Oxford: Oxford University Press.

Trotsky, Leon. (1924) 2007. Literature and Revolution. Tłum. Rose Strunsky. https://www.marxists.org/archive/trotsky/1924/lit_revo/.

Wark, McKenzie. 2015. Molecular Red: Theory for the Anthropocene. London - New York: Verso.

Žižek, Slavoj. 2018. "Evald Ilyenkov's Cosmology: The Point of Madness of Dialectical Materialism.” The Philosophical Salon, December, 10, https://hephilosophicalsalon.com/evald-ilyenkovs-cosmology-thepoint-of-madness-of-dialectical-materialism/.

-. 2021. Hegel i mózg podłączony. Tłum. Maciej Kropiwnicki. Warszawa: Wydawnictwo Krytyki Politycznej.

\section{Cytowanie:}

Wójcik, Bartosz. 2021. "Komunizm kosmiczny." Praktyka Teoretyczna 41(3): 7-15.

DOI: $10.14746 /$ prt.2021.3.1

Author: Bartosz Wójcik

Title: Cosmic Communism 